\title{
DEMOGRAPHIC CHARACTERISTICS AND PSYCHOLOGICAL EMPOWERMENT ON SERVICE ORIENTATION: A STUDY IN YOGYAKARTA, INDONESIA
}

Adita Bagus SAPUTRO ${ }^{1}$ Ignatius Soni KURNIAWAN ${ }^{2 *}$

Received: November 2019 | Accepted: December 2019 | Published: August 2020

Please cite this paper as: Saputro, A. B., Kurniawan, I. S. (2020). Demographic characteristics and psychological empowerment on service orientation: a study in Yogyakarta, Indonesia, Holistica Journal of Business and Public Administration, vol. 11, iss. 2, pp. 63-73

\begin{abstract}
The service quality in hotels can be seen first from the front-office that interacts directly with customers, here service orientation has an important role. Employees who have high service orientation will have high performance and can be a competitive advantage for the company. Psychological empowerment also an important factor in service orientation, it can be seen from the feelings shown by employees and can increase self-recognition and self-esteem. This research aims to determine the influence of demographic characteristics and psychological empowerment towards service orientation in the hospitality industry. This research was conducted at several three-star hotels in Yogyakarta. This research used multiple regression analysis, partial $t$ test, coefficient of determination and beta standardized coefficient to analyse the data. Furthermore, the results of this research are gender, age, education level and competency certification have a positive and significant influence on service orientation. Meanwhile, tenure has a negative and insignificant influence and marital status has a positive and insignificant influence on service orientation. The last, psychological empowerment has a positive and significant influence on service orientation.
\end{abstract}

Keywords: demographic characteristics, psychological empowerment, service orientation.

JEL Classification: 015

1 Sarjanawiyata Tamansiswa University of Economics Faculty, Yogyakarta, Indonesia, adityabsaputro@gmail.com

2 Sarjanawiyata Tamansiswa University of Economics Faculty, Yogyakarta, Indonesia, soni_kurniawan@ustjogja.ac.id

* Corresponding author 


\section{Introduction}

Yogyakarta is the one of famous cities in Indonesia after Bali. Yogyakarta presents dozens of tourist objects spread across each Regency. Based on statistical data, the number of foreign tourists staying during 2018 was 282,278 people and domestic tourists were recorded 6,243,616 people (BPS, 2018). There are many choices of hotels in Yogyakarta, based on statistics from the Central Statistics Agency of Yogyakarta (BPS, 2018) there are 143 star hotels and 1,475 non-star hotels. The number of star hotels in Yogyakarta encourage each hotel to compete in attracting tourists to stay at their hotels. The hotels have to prioritise guest satisfaction by maintaining service quality (Chen, 2007). Front office employees play an important role in the hospitality industry, and their behavior will directly influence the first impression on guests, front office employees who provide the best service to guests can increase the company's competitive advantage, enhance reputation and enhance guests' desire to come back (Bardi, 2003).

Employee behavior and knowledge are positively related to service orientation, and service orientation is positively related to the training process (Yen, Yeh \& Lin, 2016). Several studies have confirmed that demographic characteristics also influence employee's service orientation (Ivkov et al., 2016; Yen, Yeh \& Lin, 2016; Kim et al., 2003; Hogan et al., 1984). But there are still differences in results among some of the studies. In general, demographic variables such as gender, marital status, tenure and age show differences from different studies.

Employees will have a better service orientation if they receive higher empowerment and are entrusted with more responsibilities, so empowerment is one of the factors that can provide better service (Yen, Yeh \& Lin, 2016). Employee empowerment is an important factor in the service industry (Yen, Yeh \& Lin, 2016). The purpose of this study is to examine models in different populations and to find out the clear relationship between demographic characteristics and psychological empowerment with service orientation.

\section{Literature Review, and Hypothesis Development}

\subsection{Demographic Characteristics and Service Orientation}

Employee attitudes and behavior are very influential on the service quality, so individual characteristics need to be considered by managers when recruiting (Teng \& Barrows, 2009). In organizations, gender is often associated with strengths and traits, men are connoted to ambitious and competitive traits so that they always seek a higher position, while women are more differential and emotional so that they are good listeners and supportive of others (Pfeffer, 1983). Basically female employees more easily communicate with different customers and enjoy service activities (Yen, Yeh \& Lin, 2016).

In the study of the influence of demographic characteristics on service orientation, O'Connor et al. (2000) found that female, married and older employees had higher service orientation than other employees. In the psychology, increasing age will affect the 
HOLISTICA Vol 11, Issue 2, 2020, pp. 63-73

personality of each individual, personality continues to change and develop after the age of 20 years and its peak is reached in middle age (Helson, Jones \& Kwan, 2002). Increasing age will also increasing friendliness, and being friendly is the one factors needed in employee's service orientation.

Educational level is a long-term process that uses systematic and organized procedures, in the education they learn conceptual and theoretical knowledge, so that the educational level of an employee can improve company competitiveness and improve company performance (Robinson, Porporino \& Simourd, 1997). The higher the level of employee education, the higher the influence on service orientation, this illustrates the educational level that employees have will improve their quality, they tend to have higher insight and ability, so competence in work will increase and will have an impact on increasing quality (Reichel, Lowengart \& Milman, 2000).

Tenure can describe a person's experience in mastering his field of work, in general employees with a lot of work experience do not need guidance compared to the new employees (Abraham \& Farber, 1987). Marital status will usually increase an employee's sense of responsibility for work, and usually married employees are more satisfied with their work compared to unmarried employees (Robbins \& Judge, 2013). In the research of Kim et al. (2003) in Korea, employee tenure and employee position significantly influence service orientation. Yeh, Yeh \& Lin (2016) found that gender, age, tenure and marital status have a significant relationship with service orientation.

Competency certification is the process by which a person proves that he has the knowledge, experience and skills to do certain jobs and tasks in which they have been trained. The competency is proven in the form of certificates obtained by passing one or more examinations developed by organizations or associations that monitor and enforce the standards set for certain industries (Liu, 2013). Similar to the educational level, employees who have attended professional training and have competency certificates will affect the service orientation (Liu, 2013). Based on several previous research findings, hypothesis 1 is compiled as follows.

H1: Demographic characteristics have a positive and significant influence on service orientation.

H1a: Gender has a positive and significant influence on service orientation.

$\mathrm{H} 1 \mathrm{~b}$ : Age has a positive and significant influence on service orientation.

$\mathrm{H} 1 \mathrm{c}$ : Education level has a positive significant influence on service orientation.

H1d: Tenure has a positive and significant influence on service orientation.

H1e: Marital status has a positive and significant influence on service orientation.

H1f: Competency Certification has a positive and significant influence on service orientation. 


\subsection{Psychological Empowerment and Service Orientation}

Psychological empowerment is an individual's belief in his ability to carry out work activities related to skills and competencies (Laschinger et al., 2004). Laschinger et al. (2004) explained that psychological empowerment is related to people who are competent or able to feel empowered on work. Employees who are more competent about their abilities and psychologically empowered will tend to be more satisfied with work, more committed to organization, has low intention to stop working and has high performance. Spreitzer (1995) measured psychological empowerment in the workplace with four indicators: 1) impact; 2) competence; 3) meaning; and 4) self-determination.

Hechanova, Alampay \& Franco (2006) revealed that empowerment has a positive relationship with service quality, empowerment is important in service, because every organization needs employees who are fast, responsive and independent, so that companies have competitive advantages through the employees. Some research confirmed that empowerment has a positive relationship with service quality (Boudrias, Gaudreau \& Laschinger, 2004; Stander \& Rothmann, 2009). Empowerment can improve performance of employees to provide better service quality, increase loyalty and care among employees. Other research in the hospitality industry found that employees who get more support from the company and their supervisors will improve customer service orientation (Susskind, Kacmar \& Borchgrevink, 2017).

Service orientation is the desire to help or serve others to meet their needs, which means trying to know and meet customer needs, take responsibility for solving customer problems and even act as an advisor in dealing with customer problems and needs (Yen, Yeh \& Lin, 2016). People who have a service orientation will focus on providing satisfaction and making themselves always available to others (Merlo et al., 2006). Dlenhart, Gregoire \& Downey (1990) stated that service orientation in the hospitality industry should have three indicators: 1) service under pressure; 2) organizational support; 3) customer focus; and Yen, Yeh \& Lin (2016) added "relationship with customers" as indicator's needed to measure service orientation.

Spreitzer (1995) indicated psychological empowerment is a reflection of employees' feelings towards empowerment, when employees feel psychological empowerment from the company, it means they get it from supervisors or company support. Based on several previous research findings, hypothesis 2 is compiled as follows:

H2: Psychological empowerment has a significant positive influence on service orientation.

\section{Method}

This research used multiple linear regression analysis, partial $t$ test, coefficient of determination and beta standardized coefficient to analyse the relationship between the variables. In analysing data obtained from respondents' answers to prove the hypothesis 
HOLISTICA Vol 11, Issue 2, 2020, pp. 63-73

that has been formulated, the data is processed using the SPSS 24 program. Before conducting a multiple linear regression analysis, the data that has been obtained are first tested for validity and reliability to strengthen the results of the questionnaire. The data in this study are measured by 5 Likert scale. Because this study uses one-tail testing, the p-value must be divided by 2 (Heale \& Twycross, 2015).

The population in this study were front office employees from 7 three-star hotels in Yogyakarta, with 59 employees in total. Because the total employee population is less than 100 people, all employees are sampled (Norušis, 2016). The sampling technique in this study used a total sampling technique. Total sampling is a sampling technique by taking all members of the existing population (Etikan, Musa \& Alkassim, 2016).

\section{Results}

In this research, all the items of each variable are valid. The Pearson correlation results obtained psychological empowerment variable value of $0.449 * *-0.830 * *$ and service orientation variable value of $0.397 * *-0.621 * *$. The instrument is valid if there are stars (one or two) on the correlation value (Heale \& Twycross, 2015). So that, all the items used in research can accurately express the variables. Furthermore, the questionnaire used is reliable, the result of psychological empowerment (PE) has a cronbach alpha based on standardized items of $0.850>0.8$ (good) and service orientation has a value of $0.796>0.7$ (good enough). Heale and Twycross (2015) explain, the coefficient value on good reliability is above 0.7 (good enough), above 0.8 (good) or at least above 0.6 seen from the standardized cronbach alpha value.

The results of the characteristic of respondent in this study can be summarized in Table 1 as follows:

Table 1. Characteristic of Respondent

\begin{tabular}{lccccc}
\hline & Freq & $(\%)$ & & Freq & (\%) \\
\hline Gender & & \multicolumn{5}{c}{ Tenure } \\
Female & 34 & 57.6 & $<3$ & 51 & 86.4 \\
Male & 25 & 42.4 & $>3$ & 8 & 13.6 \\
\hline Age & & & Marital Status & & \\
$18-25$ & 33 & 55.9 & Single & 42 & 71.2 \\
$26-35$ & 26 & 44.1 & Married & 17 & 28.8 \\
\hline
\end{tabular}

Education Level

Certification 
HOLISTICA Vol 11, Issue 2, 2020, pp. 63-73

\begin{tabular}{lcclcc} 
& Freq & $(\%)$ & & Freq & (\%) \\
\hline Gender & & \multicolumn{5}{c}{ Tenure } \\
Female & 34 & 57.6 & $<3$ & 51 & 86.4 \\
Male & 25 & 42.4 & $>3$ & 8 & 13.6 \\
\hline Age & & & Marital Status & & \\
Non-graduate & 22 & 40.6 & Yes & 36 & 61 \\
Under-graduate & 37 & 59.4 & No & 23 & 39 \\
\hline
\end{tabular}

Source: Author, 2019.

The results of the multiple linear analysis in this study can be summarized in Table 2 as follows:

Table 2. The Regression Result

\begin{tabular}{lccccc}
\hline & \multicolumn{2}{c}{$\begin{array}{c}\text { Unstandardized } \\
\text { Coefficients }\end{array}$} & $\begin{array}{c}\text { Standardized } \\
\text { Coefficients }\end{array}$ & & \\
\cline { 2 - 4 } & B & Std. Error & Beta & t & Sig. \\
\hline (Constant) & 40.357 & 4.942 & & 8.167 & .000 \\
GE - SO & 2.022 & .990 & .213 & 2.043 & .046 \\
AG - SO & 2.697 & 1.133 & .285 & 2.380 & .021 \\
EL-SO & 5.124 & .974 & .528 & 5.260 & .000 \\
TN-SO & -.471 & 1.513 & -.034 & -.311 & .757 \\
MS - SO & 1.320 & 1.142 & .127 & 1.156 & .253 \\
CC-SO & 2.291 & .984 & .238 & 2.328 & .024 \\
PE-SO & .435 & .106 & .399 & 4.093 & .000 \\
\hline
\end{tabular}

Source: Author, 2019. 


\subsection{Demographic Characteristics and Service Orientation}

Regression models have met the classical assumption test. Based on Table 2. Regression table shows that $p$-value for the influence of gender (GE) on service orientation (SO) after being divided by 2 is 0.023 ( $p$-value $<0.05$ ) and the t-test value is 2.043 ( $t$-test value $>t$ table 1.67528). So it can be stated that Gender has a positive and significant influence on service orientation. In this study, hotel front-office employees were $57.6 \%$ women (Table 1), which basically women employees more easily communicate with different customers and enjoy service activities (Yen, Yeh \& Lin, 2016). The finding is consistent with the research of Yen, Yeh \& Lin (2016).

Based on Table 2. Regression table shows that $p$-value for the influence of age (AG) on service orientation after being divided by 2 is 0.0105 ( $p$-value $<0.05$ ) and t-test value 2.380 (t-test value $>\mathrm{t}$-table 1.67528). So it can be stated that age has a positive and significant influence on service orientation. In this study, hotel front-office employees were 44.1\% 26-35 years-old (Table 1). As an employee's age increases, his service orientation will also increase. Affirmed by Kersting (2003) the older a person is, the more friendly their personality will be, which is needed in service orientation. The finding is consistent with the research of Yen, Yeh \& Lin (2016).

Based on Table 2. Regression table shows that $p$-value for the influence of educational level (EL) on service orientation after being divided by 2 is 0,000 ( $p$-value $<0.05$ ) and the $\mathrm{t}$-test value is 5.260 (t-test value > t-table 1.67528). So it can be stated that the education level has a positive and significant influence on service orientation. In this study, hotel front-office employees were $59.4 \%$ under-graduate degree and the rest were nongraduate (Table 1). So that the higher level of education, the service orientation will increase, because the educational level owned by employees will improve their quality, they tend to have higher insight and ability (Reichel, Lowengart \& Milman, 2000). The finding is consistent with the research of Reichel, et al. (2000).

Based on Table 2. Regression table shows that $p$-value for the influence of tenure (TN) on service orientation after being divided by 2 is 0.378 ( $p$-value $>0.05)$ and the $t$-test value is -0.311 in a negative direction ( $t$-test value $<\mathrm{t}$-table 1.67528). So it can be stated that the tenure has a negative and insignificant influence on service orientation. In this study, hotel front-office employees were $86.4 \%$ having less than 3 years of tenure (Table 1 ). Obtained a negative and insignificant result can be interpreted as a high or increasing tenure has a small possibility that service orientation will decrease. This result is not consistent with Yen, Yeh \& Lin (2016) which stated the tenure has a significant influence on service orientation. However, the result of this study is consistent with Ali \& Davies (2019) that tenure has a negative and insignificant influence on service performance. This data is supported by Princa (HR Coordinator of the one of the hotels) which explained that hotel employees, especially front-officer will tend to get bored (burnout) with their work in one hotel, when their tenure is getting higher. So there are rarely front-office employees who work more than 4-5 years, they will move from one hotel to another as 
HOLISTICA Vol 11, Issue 2, 2020, pp. 63-73

long as their age is still sufficient as an employee requirement until they finally find a hotel that suits their personality.

Based on Table 2. Regression table shows that $p$-value for the influence of marital status (MS) on service orientation after being divided by 2 is 0.127 ( $p$-value $>0.05$ ) and the t-test value 1.156 (t-test value < t-table 1.67528). So it can be stated that marital status has a positive and insignificant influence on service orientation. This result is not consistent with Yen, Yeh and Lin (2016) which stated that marital status has a significant effect on service orientation. However, this result is consistent with Kim et al. (2003) which stated that marital status has insignificant influence on service orientation. So that employees who are married insignificantly will have a positive influence on service orientation, because basically employees who are married will have more responsibility and job satisfaction (Robbins \& Judge, 2013).

Based on Table 2. Regression table shows that $p$-value for the influence of competency certification (CC) on service orientation after being divided by 2 is 0.012 ( $p$-value $<0.05$ ) and the t-test value is 2.328 (t-test value > t-table 1.67528). So it can be stated that competency certification has a positive and significant influence on service orientation. This result is consistent with Liu (2013) which stated that competence has a significant influence on service orientation. In this study, $61 \%$ of the employees already get competency certification in hospitality (Table 1). Similar to the educational level, employees who have attended professional training and proven by competency certificates will improve the quality of employees, because they have the knowledge, experience and skills to do certain jobs and tasks where they have been trained (Liu, 2013).

\subsection{Psychological Empowerment and Service Orientation}

Based on Table 2. Regression table shows that $p$-value for the influence of psychological empowerment (PE) on service orientation after being divided by 2 is 0,000 ( $p$-value $<0.05$ ) and the t-test value is 4.093 (t-test value > t-table 1.67528). So it can be stated that psychological empowerment has a positive and significant influence on service orientation. Psychological empowerment here is how an employee sees themselves and understands how far an employee can play a role in the workplace (Laschinger et al., 2004). Researchers stated, when an employee has found a rhythm of work and consistently work according to what they believe, they will feel happy through their work. So the higher an employee feels psychologically empowered, the higher their service orientation will be. This result is consistent with Yen, Yeh \& Lin (2016).

Table 3. The Coefficient of Determination Result

\begin{tabular}{ccccc}
\hline Model & $\mathrm{R}$ & R Square & $\begin{array}{c}\text { Adjusted R } \\
\text { Square }\end{array}$ & $\begin{array}{c}\text { Std. Error of the } \\
\text { Estimate }\end{array}$ \\
\hline 1 & $.725^{\mathrm{a}}$ & .526 & .461 & 3.473 \\
\hline
\end{tabular}

Source: Author, 2019. 
Figure 1. Research Model

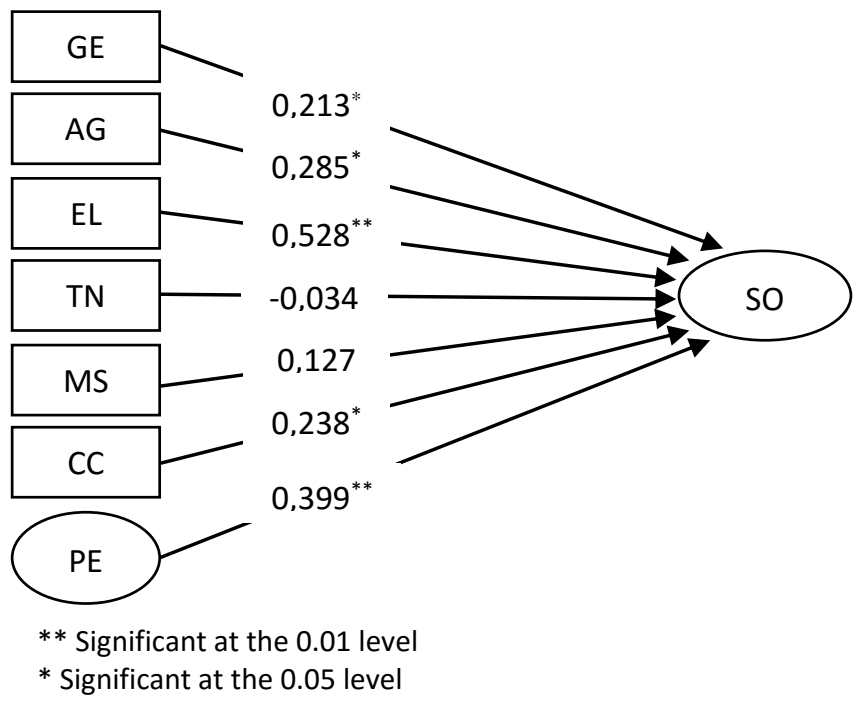

Source: Author, 2019.

\subsection{Coefficient of Determination}

Based on Table 3. The coefficient of determination table shows that the adjusted R square value is 0.461 , which means the contribution of the influence of the demographic characteristics (gender, age, educational level, tenure, marital status, competency certification) and psychological empowerment are $46.1 \%$ or can be stated sufficiently influential on service orientation, and the remaining $53.9 \%$ is influenced by variables outside the variables studied. Based on Table 1 . The beta coefficient shows that the most dominant variable influencing service orientation is the educational level $\left(0.528^{* *}\right)$, then followed by psychological empowerment $\left(0.399^{* *}\right)$ and age $\left(0.285^{*}\right)$.

\section{Discussion and Conclusions}

The findings show that gender, age, education level, competency certification are significant and positively influence service orientation. Tenure has a negative and insignificant influence, and marital status has a positive and insignificant influence on service orientation. Psychological empowerment has a significant positive influence on service orientation. The most dominant variable influencing service orientation is the educational level, then followed by psychological empowerment and age.

The negative influence shown by the variable of tenure, although insignificant, it must be the spotlight for a hotel. Psychological empowerment can not only be used to improve service orientation, but also can overcome the burnout of employees who have a high tenure as explained by Princa (HR Coordinator) in the results. So the hotels must instill positive vibes, as well as giving support and trust to every employee at work, provide sharing sessions on how to interpret work more deeply and instill the value of team 
solidarity, listen to the ideas of employees and try to implement them, appreciate what employees have given to the company, and maintain good relations between employees and the company. So that employees will feel themselves meaningful in their work environment, will have positive thoughts, and more concerned with their work and between colleagues. Automatically, service orientation will increase and burnout of tenure will decrease. Suggestion for the future research is to analyse other variables that can influence service orientation such as organizational commitment, organizational support, job satisfaction and work motivation.

\section{References}

Abraham, K. G., \& Farber, H. S. (1987). Job duration, seniority, and earnings. The American Economic Review, 77(3), 278-297.

Ali, H., \& Davies, D. R. (2003). The effects of age, sex and tenure on the job performance of rubber tappers. Journal of Occupational and Organizational Psychology, 76(3), 381-391. https://doi.org/10.1348/096317903769647238.

Bardi, James A. (2003). Hotel Front Office Management: $3^{\text {rd }}$ Edition. Hoboken, NJ: John Wiley \& Sons, Inc.

Boudrias, J.-S., Gaudreau, P., \& Laschinger, H. K. S. (2004). Testing the structure of psychological empowerment: Does gender make a difference? Educational and Psychological Measurement, 64(5), 861-877. https://doi.org/10.1177/0013164404264840.

BPS. (2018). Tingkat Penghunian Kamar Hotel Daerah Istimewa Yogyakarta 2018. Retrieved from https://yogyakarta.bps.go.id/publication.html?Publikasi\%5BtahunJudul\%5D=2018\&Publika si\%5BkataKunci\%5D=pariwisata\&Publikasi\%5BcekJudul\%5D=0\&yt0=Tampilkan.

Chen, C. F. (2007). Applying the stochastic frontier approach to measure hotel managerial efficiency in Taiwan. Tourism Management, 28(3), 696-702. https://doi.org/10.1016/j.tourman.2006.04.023.

Dlenhart, J. R., Gregoire, M. B., \& Downey, R. G. (1990). Service orientation of restaurant employees. Hospitality Research Journal, 14(2), 421-429. https://doi.org/10.1177/109634809001400245.

Etikan, I., Musa, S. A., \& Alkassim, R. S. (2016). Comparison of convenience sampling and purposive sampling. American journal of theoretical and applied statistics, 5(1), 1-4. https://doi.org/10.11648/j.ajtas.20160501.11.

Heale, R., \& Twycross, A. (2015). Validity and reliability in quantitative studies. Evidence-based nursing, 18(3), 66-67. http://dx.doi.org/10.1136/eb-2015-102129.

Hechanova, M. R. M., Alampay, R. B. A., \& Franco, E. P. (2006). Psychological empowerment, job satisfaction and performance among Filipino service workers. Asian Journal of Social Psychology, 9(1), 72-78. https://doi.org/10.1111/j.1467-839X.2006.00177.x.

Helson, R., Jones, C., \& Kwan, V. S. Y. (2002). Personality change over 40 year of adulthood: Hierarchial linear modeling analyses of two longitudinal samples. Journal of personality and social psychology, 83(3), 752-766. https://doi.org/10.1037/0022-3514.83.3.752.

Hogan, J., Hogan, R., \& Busch, C. M. (1984). How to measure service orientation. Journal of Applied Psychology, 69(1), 167-173. https://doi.org/10.1037/0021-9010.69.1.167.

Ivkov, M., Blešić, I., Božić, S., \& Đeri, L. (2016). Service orientation as a basis for quality services and competitiveness in hotel industry. SITCON 2016 - Singidunum International Tourism Conference, Beograd, 199-202. https://doi.org/10.15308/Sitcon-2016-199-202. 
HOLISTICA Vol 11, Issue 2, 2020, pp. 63-73

Kersting, K. (2003). Personality changes for the better with age. Retrieved November 1, 2019, from American Psychological Association website: https://www.apa.org/monitor/julaug03/personality.

Kim, H. J., McCahon, C., \& Miller, J. (2003). Service orientation for contract employees in Korean casual-dining restaurants. International Journal of Hospitality Management, 22(1), 67-83. https://doi.org/10.1016/S0278-4319(02)00073-7.

Laschinger, H. K. S., Finegan, J. E., Shamian, J., \& Wilk, P. (2004). A longitudinal analysis of the impact of workplace empowerment on work satisfaction. Journal of Organizational Behavior, 25(4), 527-545. https://doi.org/10.1002/job.256.

Liu, H. H. (2013). The role of hospitality certificates in the relationship between training and education and competency. The Anthropologist, 16(3), 505-511. https://doi.org/10.1080/09720073.2013.11891376.

Merlo, O., Bell, S. J., Mengüç, B., \& Whitwell, G. J. (2006). Social capital, customer service orientation and creativity in retail stores. Journal of Business Research, 59(12), 1214-1221. https://doi.org/10.1016/j.jbusres.2006.09.021.

Norušis, M. J. (2006). SPSS 14.0 guide to data analysis. Upper Saddle River, NJ: Prentice Hall.

O'Connor, S. J., Trinh, H. Q., \& Shewchuk, R. M. (2000). Determinants of service orientation among medical students. Advances in Health Care Management, 1, 217-249. https://doi.org/10.1016/S1474-8231(00)01010-7.

Pfeffer, J. (1983). Organizational demography. Research in Organizational Behavior, 5, 299-357.

Reichel, A., Lowengart, O., \& Milman, A. (2000). Rural tourism in Israel: service quality and orientation. Tourism management, 21(5), 451-459. https://doi.org/10.1016/S02615177(99)00099-0.

Robbins, S. P., \& Judge, T. A. (2013). Organizational behavior. Canada: Pearson Education Limited.

Robinson, D., Porporino, F. J., \& Simourd, L. (1997). The influence of educational attainment on the attitudes and job performance of correctional officers. Crime \& Delinquency, 43(1), 60-77. https://doi.org/10.1177/0011128797043001004.

Spreitzer, G. M. (1995). Psychological empowerment in the workplace: Dimensions, measurement, and validation. Academy of management Journal, 38(5), 1442-1465. https://doi.org/10.2307/256865.

Stander, M. W., \& Rothmann, S. (2009). Psychological empowerment of employees in selected organisations in South Africa. Journal of psychological industry, 35(1), 196-203. https://doi.org/10.4102/sajip.v35i1.466.

Susskind, A. M., Kacmar, K. M., \& Borchgrevink, C. P. (2007). How organizational standards and coworker support improve restaurant service. Cornell Hotel and Restaurant Administration Quarterly, 48(4), 370-379. https://doi.org/10.1177/0010880407300158.

Teng, C. C., \& Barrows, C. W. (2009). Service orientation: Antecendents, outcomes, and implications for hospitality research and practice. The Service Industry Journal, 29(10), 14131435. https://doi.org/10.1080/02642060903026247.

Yen, C. D., Yeh, C. H., \& Lin, S. Y. (2016). Psychological empowerment and service orientation: A study of front-line employees in food and beverage industry. Journal of Foodservice Business Research, 19(3), 298-314. https://doi.org/10.1080/15378020.2016.1178047. 